\title{
Assessment of the adaptive potential of the plum-tree to the conditions of the winter period in the northern forest-steppe of the Southern Urals
}

\author{
Tatyana Slepneva ${ }^{1 *}$, Sergey Makarenko ${ }^{1}$, Alexander Taranau ${ }^{2}$ \\ ${ }^{1}$ Ural federal agricultural research center of the Ural department RAS, 620142 Yekaterinburg, Russia \\ ${ }^{2}$ Republican Scientific and Production Subsidiary Unitary Enterprise "Institute For Fruit Growing", \\ 223013, Minsk district, Minsk region, ag. Samokhvalovitchy, Belarus
}

\begin{abstract}
The results of assessment are presented the stability of 13 sorts of plum-tree $P$. salicina subsp. ussuriensis Koval. et Kost. to the climatic conditions in the winter period from 2015/16 to 2020/21 in the northern forest-steppe of the Southern Urals. Like the control sort Ural'skaya zolotistaya by high adaptability to the conditions of the winter period are characterized sorts Altajskaya yubilejnaya, Zavet, Pionerka, Sapfir, Seyanec Krasnogo shara, Sodruzhestvo, Sinil'ga, Ural'skie zori, Chernosliv pozdnij. Stable fruiting over the years, regardless of weather conditions, during the flowering period with a yield of 62.0 to 91.6 hundredweight/ha are mark out with an increasing total sort Altajskaya yubilejnaya, Pionerka, Chernosliv pozdnij. The control sort Ural'skaya zolotistaya exceeds the yield of the sort Altajskaya yubilejnaya (91.6 hundredweight/ha), at the level of control the yield of the sorts Sodruzhestvo (71.5 hundredweight/ha), Sapfir (70.0 hundredweight/ha).
\end{abstract}

\section{Introduction}

One of the important conditions by growing and obtaining stable yields from stone fruit crops in a certain area is their adaptability, and in particular winter hardiness [1]. The basis of the zoned assortment in the northern zone of fruit growing in Russia - in the Far East, Siberia and the Urals are sorts of Ussuri plum-tree P. salicina subsp. ussuriensis Koval. et Kost., which allows to be grown them along the northern border of the plum-tree area.

The main limiting factor of successful plum-tree growth is resistance to low negative temperatures in winter [2].

Winter damages to plum-trees in the conditions of the Urals and the Middle Altai Mountains are caused by a complex of factors and most often occurs when early frosts occur, low negative temperatures in the middle winter period, sharp temperature fluctuations in the autumn-winter period and due to winter desiccation [3,4].

\footnotetext{
* Corresponding author: tatyana_slepneva@mail.ru
} 
The purpose of the work is to analyze the climatic conditions of the northern foreststeppe of the Southern Urals during the research period, to assess the adaptive potential of the plum-tree to the conditions of the winter period and their impact on productivity.

\section{Objects and methods of research}

The research was carried out in the department of selection and sorts study of fruit and berry crops of the Sverdlovsk selection station of gardening - structural subdivision of the FGBNU Ural Federal Agrarian Research Center of the Ural Branch of the Russian Academy of Sciences during 2016-2020. The research was carried out according to the State task of the Ministry of Education and Science of the Russian Federation in the direction of the Program 150 of the of Fundamental scientific research of the State Academies of Sciences.

The research was carried out in the northern forest-steppe zone of the Southern Urals on the Chelyabinsk State Fruit and berry sort-testing lot located in the Krasnoarmeysky district of the Chelyabinsk region.

Objects of study -13 sorts of Ussuri plum-tree $P$. salicina subsp. ussuriensis Koval. et Kost. (table 1).

Table 1. Research objects and their origin

\begin{tabular}{|l|r|}
\hline \multicolumn{1}{|c|}{ Sort } & \multicolumn{1}{|c|}{ Origin $+\mathrm{x}{ }^{\wedge}$} \\
\hline $\begin{array}{l}\text { Sorts, which are created in the conditions of the Southern Urals (South Ural Scientific Research Institute } \\
\text { of Horticulture and Potato Growing - branch of the Ural Federal Agrarian Research Center Ural Branch } \\
\text { of the Russian Academy of Sciences) }\end{array}$ \\
\hline $\begin{array}{l}\text { Ural'skaya zolotistaya *- } \\
\text { (st) }\end{array}$ \\
\hline Zhemchuzhina Urala \\
(Department of the M.A. Lisavenko Research Institute of the Federal Altai Scientific Center of \\
Agrobiotechnologies)
\end{tabular}




\begin{tabular}{|l|r|}
\hline Zavet & Seedling from free pollination of the sort Man'chzhurskaya krasavica \\
\hline Pionerka* & Seedling from free pollination of Pr. salicina subsp. ussuriensis \\
\hline Rakityanskaya & Seedling from free pollination of Pr. salicina subsp. ussuriensis \\
\hline Sodruzhestvo* & Immunnaya x 14-26 (Pr. salicina subsp. ussuriensis) \\
\hline Ural'skie zori* & Seedling from free pollination of Pr. salicina subsp. ussuriensis \\
\hline
\end{tabular}

Note: * - sorts, which are zoned in the Ural region.

The studied sorts were planted in the autumn of 2009 according to the methodology of the state sort-testing [5]. The planting scheme is $5 \times 3 \mathrm{~m}$. The repetition is 3-divisibly with 10 plants in each. The rootstock, which is zoned in the Ural region - Prunus bessyi. Agrotechnics is generally accepted for plum-trees, a plot on the dry-farming land. The assessment of the degree of freezing, the general state and yield was carried out in accordance with generally accepted methods [6].

\section{Results and discussion}

The climatic conditions during the study period (2016-2020) are shown in Figure 1. The average annual air temperature was higher in comparison with long-term data $\left(+2.1^{\circ} \mathrm{C}\right)$ : in $2016 / 17$ by $1.6^{\circ} \mathrm{C}$, in $2017 / 18$ - by $0.1^{\circ} \mathrm{C}$, in $2018 / 19$ - by $0.2^{\circ} \mathrm{C}, 2019 / 20$ - by $0.8^{\circ} \mathrm{C}$, $2020 / 21$ - by $3.0^{\circ} \mathrm{C}$.

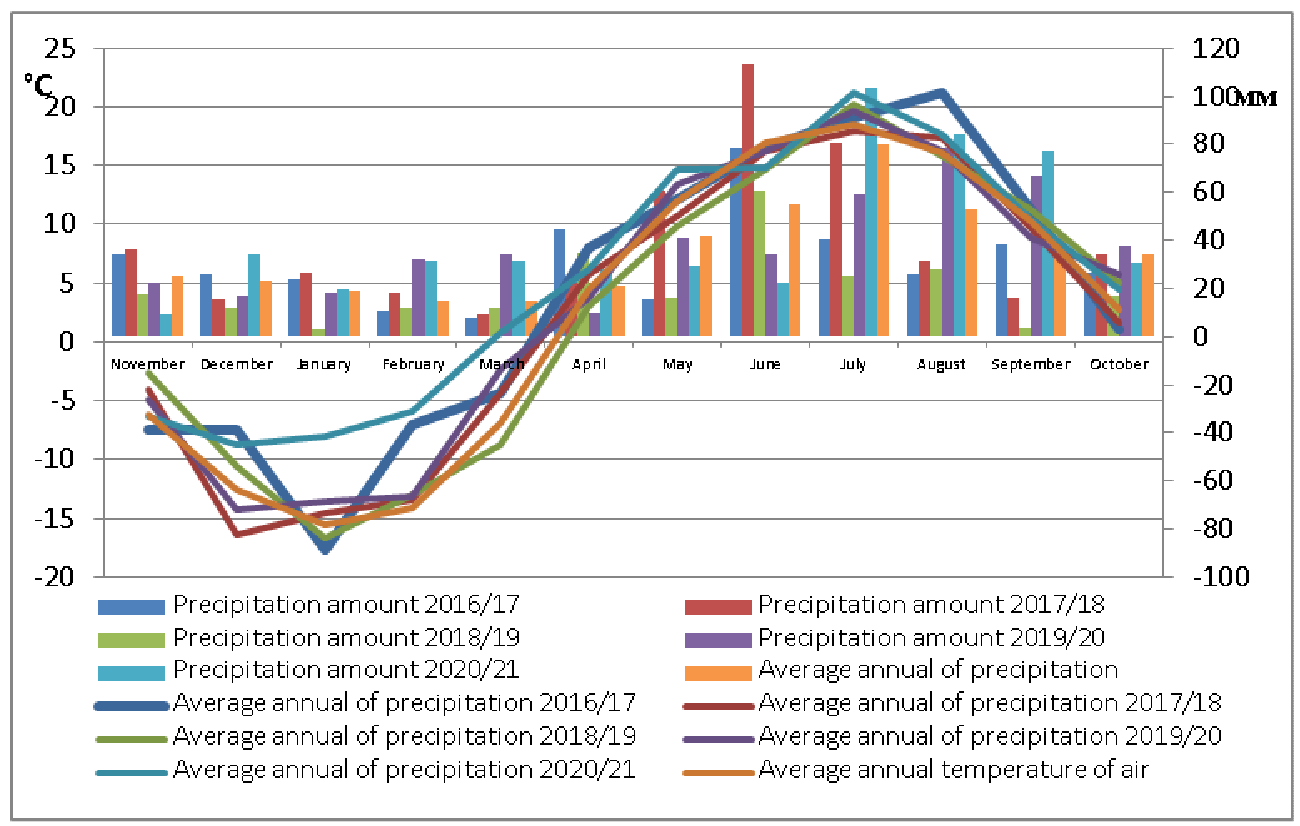

Fig. 1. Climatic conditions in the years of research 2016-20201 (according to the data of the Chelyabinsk State University Center for Hydrometeorology and Environmental Monitoring - the village weather station Brodokalmak, Krasnoarmeysky district, Chelyabinsk region).

The average monthly air temperature in January 2016 was lower than the average annual values $\left(-15.4{ }^{\circ} \mathrm{C}\right.$ ) by $2.3{ }^{\circ} \mathrm{C}$, in 2018 by $1.3{ }^{\circ} \mathrm{C}$. The absolute minimum of air 
temperature was marked in January $2016-35.5{ }^{\circ} \mathrm{C}\left(-38.0{ }^{\circ} \mathrm{C}\right.$ on the snow surface), in December $2017-38.3{ }^{\circ} \mathrm{C}\left(-42.2{ }^{\circ} \mathrm{C}\right.$ on the snow surface) and in February $2019-37.6{ }^{\circ} \mathrm{C}(-$ $41.3{ }^{\circ} \mathrm{C}$ on the snow surface).

In the years of research were noted dry periods during the growing season. Thus in 2016, during mass maturing of the crop and in autumn when preparing plants for wintering was observed a deviation from the norm ( $424 \mathrm{~mm}$ per year) by $52.0 \mathrm{~mm}$, in 2018 by 183.3 mm. Insufficient supply of moisture in July and August was noted in 2016 - less than the norm by $52.9 \mathrm{~mm}$ and in 2018 - less than the norm by $183.3 \mathrm{~mm}$, which affected the decrease in the average weight and taste of fruits.

The control sort of the plum-tree Ural'skaya zolotistaya in all the years of research showed high winter hardiness of the tree and only in the winter period of 2016/17 with a decrease in the air temperature in December to $-38.3{ }^{\circ} \mathrm{C}$, and on the snow surface to $42.2{ }^{\circ} \mathrm{C}$ had a slight damage to the wood on average 0.3 points (table 2 ).

High winter hardiness at the control level in all the years of research with reversible damage of wood no more than 0.9 points was noted by sorts - Altajskaya yubilejnaya, Zavet, Pionerka, Sapfir, Seyanec krasnogo shara, Sodruzhestvo, Sinil'ga, Ural'skie zori, Chernosliv pozdnij. Reversible damage to wood after the winter period of 2019/20 had sort Zhemchuzhina Urala -1.1 points. The sort Kseniya has an average winter hardiness in the conditions of the northern forest-steppe of the Southern Urals, with almost annual damage to wood up to $2.5-2.8$ points.

The general state of the plants by the control sort and the studied sorts can be described as excellent.

An essential influence on the state of the sort plum-tree Kseniya from satisfactory to good was exerted by the degree of freezing of the wood, the conditions for providing moisture during the growing season and the degree of fruiting.

Table 2. Assessment of the degree of freezing and the general state of the plum-tree 2016-2020

\begin{tabular}{|l|c|c|c|c|c|c|c|c|c|c|}
\hline \multirow{2}{*}{ Sorts } & \multicolumn{5}{|c}{ Degree of freezing, marks } & \multicolumn{4}{c|}{ General state, marks } \\
\cline { 2 - 12 } & 2016 & 2017 & 2018 & 2019 & 2020 & 2016 & 2017 & 2018 & 2019 & 2020 \\
\hline Ural'skaya zolotistaya - st & 0 & 0.3 & 0 & 0 & 0 & 5.0 & 5.0 & 5.0 & 4.7 & 4.6 \\
\hline Altajskaya yubilejnaya & 0.1 & 0.8 & 0.1 & 0.1 & 0.6 & 4.7 & 4.8 & 5.0 & 5.0 & 4.8 \\
\hline Zhemchuzhina Urala & 0.1 & 2.0 & 0.9 & 0.9 & 1.1 & 5.0 & 5.0 & 5.0 & 5.0 & 4.9 \\
\hline Zavet & 0 & 0 & 0 & 0 & 0.8 & 5.0 & 5.0 & 4.9 & 4.9 & 4.8 \\
\hline Kseniya & 0 & 2.8 & 2.8 & 2.5 & 0.6 & 4.5 & 4.3 & 3.9 & 3.9 & 4.0 \\
\hline Pionerka & 0.2 & 0.2 & 0.1 & 0.1 & 0.8 & 5.0 & 4.9 & 4.8 & 4.8 & 4.8 \\
\hline Rakityanskaya & 0.2 & 0.4 & 0 & 0.3 & 0.5 & 4.8 & 4.9 & 4.8 & 4.9 & 4.6 \\
\hline Sapfir & 0 & 0 & 0.2 & 0.2 & 0.9 & 5.0 & 5.0 & 4.9 & 5.0 & 4.9 \\
\hline Seyanec krasnogo shara & 0.1 & 1.0 & 0.5 & 0.1 & 0.5 & 5.0 & 5.0 & 4.6 & 4.9 & 4.8 \\
\hline Sinil'ga & 0 & 0 & 0 & 0.1 & 0.3 & 5.0 & 5.0 & 4.9 & 4.8 & 4.9 \\
\hline Sodruzhestvo & 1.3 & 1.0 & 0.1 & 0.1 & 0.6 & 4.9 & 5.0 & 4.9 & 4.6 & 4.8 \\
\hline Ural'skie zori & 0.2 & 1.0 & 0.1 & 0.1 & 0.3 & 5.0 & 5.0 & 4.7 & 5.0 & 4.8 \\
\hline
\end{tabular}




\begin{tabular}{|l|l|l|l|l|l|l|l|l|l|l|}
\hline Chernosliv pozdnij & 0.3 & 0.2 & 0 & 0.5 & 0.9 & 4.9 & 5.0 & 5.0 & 4.9 & 4.9 \\
\hline
\end{tabular}

Yield is one of the main signs, that determine the value of the sort [7]. The yield of sorts plum-trees varied depending on the climatic conditions during the flowering and growing season. Depending on the year of research, the yield of the control sort Ural'skaya zolotistaya varied from 2.1 (2019) to 139.1 hundredweight/ha (2018). The average yield according to the results of many years researches was 73.0 hundredweight/ha (Table 3 ).

The average many years yield is significantly higher than, that by the control sort Altajskaya yubilejnaya 91.6 hundredweight/ha (+18).

At the control level, the yield over the years of researches was noted by the sorts Sapfir - $70.0(-3.0)$ and Sodruzhestvo - $71.5(-2.5)$, as well as the yield is some lower by sorts Pionerka, Chernosliv pozdnij and Ural'skie zori from 59.2 to 65.1 hundredweight/ha. The others sorts are significantly inferior in yield to the control sort.

Stable fruiting over the years regardless from weather conditions during the flowering period with high and medium yields with an increasing total are distinguished sorts Altajskaya yubilejnaya, Pionerka, Chernosliv pozdnij.

Table 3. Yield of Plum-tree, 2016-2020 (hundredweight/ha)

\begin{tabular}{|l|c|c|c|c|c|c|c|}
\hline \multicolumn{1}{|c|}{ Sort } & 2016. & 2017 & 2018 & 2019 & 2020 & Average & $\begin{array}{c}\text { Deviation } \\
\text { from st }\end{array}$ \\
\hline Ural'skaya zolotistaya - st & 63.0 & 32.9 & 139.1 & 2.1 & 127.9 & 73.0 & - \\
\hline Altajskaya yubilejnaya & 49.3 & 28.7 & 61.0 & 84.1 & 2349 & 91.6 & +18.0 \\
\hline Zhemchuzhina Urala & 15.5 & 19.7 & 18.3 & 20.5 & 96.1 & 34.0 & -39.0 \\
\hline Zavet & 0 & 30.2 & 58.7 & 42.1 & 61.9 & 38.6 & -35.0 \\
\hline Kseniya & 102.0 & 0 & 28.0 & 31.2 & 3.3 & 32.9 & -40.1 \\
\hline Pionerka & 33.1 & 36.7 & 57.6 & 69.1 & 129.1 & 65.1 & -7.9 \\
\hline Rakityanskaya & 52.2 & 90.0 & 86.9 & 7.1 & 40.1 & 55.2 & -17.8 \\
\hline Sapfir & 54.7 & 31.1 & 106.9 & 57.0 & 100.1 & 70.0 & -3.0 \\
\hline Sodruzhestvo & 9.5 & 160.9 & 58.7 & 45.3 & 83.3 & 71.5 & -2.5 \\
\hline Seyanec krasnogo shara & 20.0 & 23.6 & 59.1 & 50.9 & 52.1 & 41.1 & -31.9 \\
\hline Sinil'ga & 52.1 & 48.3 & 56.2 & 38.6 & 65.1 & 52.1 & -20.9 \\
\hline Ural'skie zori & 61.0 & 114.5 & 44.9 & 2.9 & 72.8 & 59.2 & -13.8 \\
\hline Chernosliv pozdnij & 52.1 & 40.2 & 59.3 & 93.6 & 65.1 & 62.0 & -11.0 \\
\hline $\begin{array}{l}\text { The smallest significant } \\
\text { difference } 05\end{array}$ & & & & & & & 8.8 \\
\hline & & & & & & & \\
\hline According to the methe & & & & & & & \\
\hline
\end{tabular}

According to the methodology the sorts were divided into medium-yielding (60-120 hundredweight/ha) by yield - Ural'skaya zolotistaya (control), Altajskaya yubilejnaya, Sapfir, Sodruzhestvo, Chernosliv pozdnij and low-yielding ( $\leq 60$ hundredweight/ha) - 
Zhemchuzhina Urala, Zavet, Kseniya, Rakityanskaya, Sinil'ga, Seyanec krasnogo shara, Ural'skie zori.

\section{Conclusions}

Thus, the climatic conditions during the years of research reflected the features of the continental climate of the Chelyabinsk region, which allowed it to assess the adaptability of sorts plum-tree to the conditions of the winter period.

High winter hardiness on the level of the control sort Ural'skaya zolotistaya, was noted by sorts - Altajskaya yubilejnaya, Zavet, Pionerka, Sapfir, Seyanec krasnogo shara, Sodruzhestvo, Sinil'ga, Ural'skie zori, Chernosliv pozdnij.

It was established that the sort control Ural'skaya zolotistaya is characterized by a yield of 73.0 hundredweight/ha. The control sort is higher in yield than the sort sort Altajskaya yubilejnaya (91.6 hundredweight/ha), at the level of productivity by the sort Sodruzhestvo (71.5 hundredweight/ha) and Sapphire (70.0 hundredweight/ha).

\section{References}

1. A. V. Solonkin, O. A. Nikolskaya, E. N. Kikteva, Bulletin of the Nizhnevolzhsky agrouniversity complex: Science and higher professional education, 2 (58) (2020)

2. V. S. Yakovleva, L. G. Setkova, Agrarian Bulletin of Primorye, 2(14) (2019)

3. M. N. Matyunin, Biological features and selection of stone crops in the Altai Mountains (Novosibirsk, 2016)

4. F. M. Gasymov, Resistance of generative buds of plum varieties to the extreme conditions of winter 2016-2017 in the South Urals. Topical issues of modern natural science of the Southern Urals. Materials of the III All-Russian Scientific and Practical Conference, December 21, Chelyabinsk (2018)

5. Methods of state variety testing of agricultural crops (Moscow, Kolos, 1970)

6. E. N. Dzhigadlo, A. F. Kolesnikova, G. V. Eremin, T. V. Morozova, S. Yu. Debiskaeva, M. V. Kanshina, N. I. Medvedeva, V. S. Simagin, Program and methodology of variety study of fruit, berry and nut crops (Orel, VNIISPK, 1999)

7. V. S. Simonov, Gardening and viticulture, 3 (2010) 